\title{
Reflexe dílčích výsledků z výzkumné studie zaměřené na připravenost k zahájení povinné školní docházky ${ }^{1}$
}

\section{Reflection of preliminary results from research study focused on readiness for beginning compulsory school education}

Eva Šmelová, Alena Petrová, Irena Plevová

\begin{abstract}
Abstrakt: Př́íspěvek je věnovaný problematice školní připravenosti z pedagogickopsychologického hlediska. Zaměřuje se na deskripci zkoumané oblasti a následně se věnuje vlastnímu výzkumnému záměru a dílčím výsledkům výzkumu.
\end{abstract}

Klíčová slova: školní připravenost, kurikulum, předškolní vzdělávání, testové baterie, předškolní pedagog, mateřská škola, základní škola.

\begin{abstract}
The article deals with the school maturity from the pedagogical-psychological view. At first, it focuses on theoretical description of investigated area. Subsequently, the paper discusses the research aim and preliminary results.
\end{abstract}

Keywords: school readiness, curriculum, preschool education, set of tests, preschool educationalist, kindergarten, basic school

\section{Informace o výzkumném záměru}

Cílem projektu je objektivně ověřit a vyhodnotit úroveň prripravenosti dětí pro úspěšné zahájení povinné školní docházky, a to s ohledem na pohlaví a př́ípadné handicapy v kontextu Rámcového vzdělávacího programu pro předškolní vzdělávání. Zpracovat komplexní pedagogicko-psychologicko-speciálně pedagogický pohled na možnost předškolního vzdělávání pozitivně ovlivnit vstup dítěte do školy v ČR. Prostřednictvím jednotné testové baterie provést šetření zaměřené na školní připravenost ve vybraných zemích Evropské unie, data komparovat.

Řešitelský tým tvoří odborníci z oblasti preprimárního a primárního vzdělávání, psychologové a speciální pedagogové působící na PdF UP v Olomouci, kteří v rámci výzkumu spolupracují se zahraničními vysokoškolskými pracovišti (Polsko, Slovinsko, Slovensko).

\subsection{Organizace výzkumného šetření a použité metody zkoumání}

Šetření je s každým dítětem realizováno individuálně. Zaznamenány jsou následující údaje: pohlaví dítěte, jeho bydliště, přesný věk, lateralita, předešlý odklad školní docházky, sourozenecké pořadí a údaje o vzdělání rodičů.

\footnotetext{
${ }^{1}$ Výzkum je podporován z prostředků Grantové agentury České republiky.
} 
U každého sledovaného dítěte je také vždy zaznamenáno jeho celkové chování při vyšetření, které je posuzováno na škálách se stupnicí 1-5. Jednotlivé škály se vztahují k soustředění dítěte (koncentrace pozornosti na jednotlivé úkoly), $\mathrm{k}$ samostatnosti dítěte při práci, $\mathrm{k}$ navázání kontaktu a citovému rozpoložení dítěte při práci a $\mathrm{k}$ tělesné konstituci. Samotné vyšetření probíhá ve dvou etapách.

První část testových úkolů zahrnuje:

1. dětskou formu Ravenova testu barevných matic (Raven, 1991),

2. vystřihování geometrických tvarů (kruh, čtverec, trojúhelník),

3. orientační test školní zralosti (Jirásek, 1992),

4. zavázání tkaničky - jedná se o úkol, který zjišt’uje praktickou dovednost související s koordinací oka a ruky, tedy další orientační ověření úrovně jemné motoriky dítěte,

5. zkoušku verbálního myšlení (Jirásek, 1992).

Druhá část testových úkolů zahrnovala:

1. Edfeldtův reverzní test (Edfeldt,1992), který zjišt’uje připravenost dítěte osvojit si dovednost čtení.,

2. jednu z variant testu dynamické praxe se zaměřením na koordinaci pohybu ruky,

3. zkoušku znalostí předškolních dětí (Matějček \&Vágnerová-Strnadová, 1992),

4. úkol zaměřený na vizuomotorickou koordinaci.

\section{Dílčí výsledky z výzkumného šetření stavu školní zralosti a připravenosti}

\section{1 Výzkumný soubor}

Výzkumný soubor zahrnuje 817 českých dětí předškolniho věku (průměrný věk 6,15 let), které $\mathrm{v}$ tomto roce byly u zápisu do prvních tříd. V souboru je 424 chlapcu (jejich průměrný věk byl 6,2 let) a 393 divvek (průměrný věk 6,1 let). Větší část dětí pochází svým bydlištěm z města, kde také navštěvují mateřskou školu (526 dětí), menší část pak bydlí na vesnici (291 dětí). Většina dětí preferuje pravou ruku (742), leváci jsou ve vzorku zastoupeni 75-ti dětmi. 692 dětí má nastoupit do školy v letošním roce, 125 má navržen odklad. Vzdělání rodičů převažuje středoškolské, poté vysokoškolské a malá část rodičů má jen základní vzdělání.

\subsection{Dílči výsledky výzkumu}

Posouzení jejich chování během vyšetření probíhalo, jak bylo dříve uvedeno, pomocí pětistupňových škál, a to $\mathrm{v}$ oblasti soustředivosti, samostatnosti při práci na úkolech a regulaci citů. Jednička znamená nejlepší hodnocení a pětka nejhorší.

U výzkumného souboru se projevovala velmi dobrá soustředivost na úkoly (průměrné ohodnocení pro obě pohlaví 1,94), děti byly při práci dostatečně samostatné (průměrné ohodnocení obou pohlaví 1,76) a situaci testování velmi dobře zvládly i po stránce emocionální (průměrná známka 1,81).

I když naše data $v$ současné době teprve postupně vyhodnocujeme a budou také podrobena odbornému statistickému zpracování, pokládáme jejich uvedení na tomto místě, byt' jen $\mathrm{v}$ orientační podobě, za zajímavé a vzhledem k poměrně početnému souboru i do jisté míry zobecnitelné ve smyslu základních zjištěných trendů. 


\section{- Oblast vyspělosti jemné motoriky}

Obratnosti jemné motoriky jsme věnovali pozornost hned několika testovými úkoly. Jednalo se o dovednost vystřihování tř́ geometrických tvarů, o zavazování tkaničky, o napodobení pohybů končetin a o grafické spojování obrázki̊ na přesně vymezeném prostoru (různě široké „,cestičky“). Další informace o úrovni grafomotoriky dítěte pak poskytuje také Jiráskův test.

Celkově lze konstatovat, že výkon dětí našeho souboru prokázal v oblasti jemné motoriky přiměřený vývoj, lehce úspěšnější byla děvčata, avšak je možné, že druh úkolu zavázání tkaničky jim mohl lépe vyhovovat, chlapci, př́padně děti z vesnic by mohli preferovat např. úkoly technického rázu (stavebnice, šroubování apod.).

\section{- Připravenost $k$ nácviku čtení}

Pro tuto oblast jsme zvolili tradičně používaný a v praxi osvědčený Edfeldtův test, který předpovídá budoucí úspěšnost především v nácviku čtení. Podle testových norem dopadly naše děti v pásmu III. (tj. průměrná připravenost, průměrné HS celého souboru bylo kolem hodnoty 60). Ve výkonu podle pohlaví byly zjištěny mírné rozdíly ve prospěch chlapců. Mírné rozdíly se jeví také ve prospěch dětí bez odkladu školní docházky, vliv bydliště a laterality se neprokázal. Lze tedy shrnout, že připravenost našeho souboru pro nácvik čtení je celkově průměrná.

\section{- Jiráskův test školní zralosti (modifikace Kernova testu)}

Test se skládá ze tř́i úkolů - kresba mužské postavy, napodobení psaného písma a překreslení skupiny teček podle předlohy. Výkon ve všech třech částech je známkován $(1-5)$ podle přesně stanovených kritérií.

Při výpočtu souhrnné známky za všechny tři úkoly byl náš výzkumný soubor ohodnocen známkou 2,5. Sledovaný soubor se dá jako celek sice označit jako zralý pro zaškolení, avšak hodnoty jsou jen průměrné (vezmeme-li v úvahu praktické zkušenosti s výsledky tohoto testu, podle nichž se výsledky horší než za 3 považují obvykle za indikaci k podrobnějšímu zkoumání školní zralosti).

\section{- Jiráskův test školní zralosti - verbální myšlení}

Zkouška vhodně doplňuje předešlý test o zaměření na verbální složku osobnosti dítěte. Jedná se o otázky z každodenního života, které navozují jednoduché řešení nějakého praktického jevu. HS získali vyšší v tomto testu překvapivě chlapci (13,26 oproti 11,98 bodů dívek) a pak také děti bez odkladu školní docházky. Nahlédnutím do převodové tabulky získal náš soubor za dosažené hrubé skóre průměrnou známku, která odpovídá pásmu spadajícímu ke známce 3 (horní hranice, opět klasifikace jako ve škole 1-5). Dá se tedy konstatovat, že děti jsou v této oblasti připraveny spíše problematicky.

\section{- Znalosti předškolních dětí}

Zkouška patří opět k nejčastěji využívaným diagnostickým pomůckám k posouzení rozvoje osobnosti předškolního dítěte. Dalo by se předpokládat, že výsledky této zkoušky mohou korespondovat $\mathrm{s}$ předešlou metodou Jiráskova testu verbálního myšlení. Tento předpoklad náš výzkum potvrdil. Chlapci projevili také v této zkoušce znalostí mírně lepší výkon (HS 23,7 oproti dívkám s 21,3 bodu), stejně jako děti bez odkladu ve srovnání se skupinou s odkladem školní docházky. Jiné rozdíly zaznamenány nebyly. Celkový průměrný výkon celého výzkumného vzorku byl 22,7 bodu, neboli náš soubor předškoláků je tímto v průměrném pásmu kognitivních schopností, a to při spodní hranici průměrného pásma kognitivních schopností. 


\section{- Artikulační obratnost}

Pro pouze orientační zachycení vad výslovnosti byl použit soubor artikulačně náročných slov, které děti po examinátorovi opakovaly.

Byl zaznamenáván počet správných slov, který byl v průměru u celého souboru dětí 3,6, bez rozdílů mezi skupinami.

\section{- Orientační pásmo inteligence}

Vrozené dispozice voblasti inteligence lze zachytit pomocí standardizované metody Ravenova testu. Jde o neverbální zkoušku, výkon v ní není významněji ovlivněn prostředím. Výsledky našeho souboru (průměrné HS 18,87) lze zařadit do pásma průměru až lehkého nadprůměru, s minimálními rozdíly mezi sledovanými skupinami. S jistým zjednodušením můžeme konstatovat, že intelektové předpoklady by našemu vzorku neměly bránit v úspěšném zaškolení.

\section{Závěrem}

Jsme si vědomi, že uvedené souhrnné výsledky prezentované prostřednictvím průměrných hodnot našeho souboru jsou v této fázi spíše orientační informací. Domníváme se, že podrobné statistické zpracování odhalí hodnotnější souvislosti sledovaných jevů, jejichž analýzou se pak lze dobrat $\mathrm{k}$ přesnějšímu obrazu současného stavu českých dětí v kontextu s jejich pravděpodobností úspěchu při nástupu povinné školní docházky.

\section{Literatura}

Edfeldt, A. W. (1992). Reverzný test-príručka. Bratislava: Psychodiagnostika.

Jirásek, J. (1992). Orientační test školní zralosti - př́ručka. Bratislava: Psychodiagnostika.

Matějček, Z., \& Vágnerová-Strnadová, M. (1992). Zkouška znalostí předškolních dětí. Bratislava: Psychodiagnostika, 1992.

Raven, J. C. (1991). Ravenove progresivné matice farebné - príručka. Bratislava: Psychodiagnostika.

\section{Kontakt}

doc. PhDr. Alena Petrová, Ph.D.

doc. PhDr. Irena Plevová, Ph.D.

Univerzita Palackého v Olomouci

Pedagogická fakulta, Katedra psychologie a patopsychologie

Žižkovo nám. 5, 77900 Olomouc

e-mail: alena.petrova@upol.cz irena.plevova@upol.cz

doc. PhDr. Eva Šmelová, Ph.D.

Univerzita Palackého v Olomouci

Pedagogická fakulta, Katedra primární pedagogiky

Žižkovo nám. 5, 77900 Olomouc

e-mail: eva.smelova@upol.cz 


\section{Bibliografické údaje}

Šmelová, E., Petrová, A., \& Plevová, I. (2011). Reflexe dílčích výsledků z výzkumné studie zaměřené na připravenost k zahájení povinné školní docházky. In T. Janík, P. Knecht, \& S. Šebestová (Eds.), Smísený design v pedagogickém výzkumu: Sborník príspěvků z 19. výroční konference České asociace pedagogického výzkumu (s. 333-337). Brno: Masarykova univerzita.

Dostupné z: http://www.ped.muni.cz/capv2011/sbornikprispevku/smelovapetrovaplevova.pdf doi: $10.5817 /$ PdF.P210-CAPV-2012-64 